\title{
FAKTOR-FAKTOR PENGARUH PERUBAHAN KONDISI FISIK LAHAN PASCAREKLAMASI DI PULAU SERANGAN
}

\author{
I Gede Surya Darmawan, S.T., M.T. \\ Dosen Jurusan Teknik Arsitektur, Fakultas Teknik, Universitas Warmadewa, Denpasar \\ E-mail : gdsuryadarmawan@gmail.com \\ I Wayan Wirya Sastrawan, S.T., M.Sc. \\ Dosen Jurusan Teknik Arsitektur, Fakultas Teknik, Universitas Warmadewa, Denpasar \\ E-mail : wayanwiryasastrawan@gmail.com
}

\begin{abstract}
Abstrak
Reklamasi Pulau Serangan tahun 1995-1998, telah menghasilkan perubahan kondisi fisik lahan yaitu mengubah luas Pulau Serangan menjadi 4 kali lipat dari luas sebelumnya (111 hektar menjadi 481 hektar), serta menyatukan wilayah Pulau Serangan yang pada prareklamasi berupa gugusan pulau. Reklamasi yang dilakukan pertama kali di Bali ini tentunya dilatarbelakangi dengan suatu alasan-alasan tertentu, termasuk ketidaksesuaian tujuan perencanaan awal dengan realita pascareklamasi yang mana sebagian besar lahan menjadi lahan kosong, padahal ide awalnya adalah membangun fasilitas megawisata seperti golf, resort, lagoon, yatch club, beach club house, pembangunan superlot yang berupa villa, fasilitas penunjang pariwisata lainnya, serta marina/ferry. Reklamasi tersebut telah menghasilkan perubahan kondisi fisik lahan secara makro (global) dan mikro (terperinci). Berdasarkan fenomena inilah, akan dicari tahu hal-hal yang melatarbelakangi perubahan kondisi fisik lahan pascareklamasi. Metode penelitian yang digunakan adalah kualitatif deskriptif dengan teknik observasi, survey dan dokumen. Pengambilan sampel dilakukan dengan cara purposive sampling. Hasil dari penelitian ini adalah faktor-faktor yang melatarbelakangi perubahan kondisi fisik lahan pascareklamasi yaitu faktor fisik lahan, ekonomi, kelembagaan dan faktor-faktor lain seperti faktor sosial, budaya, dan kepercayaan.
\end{abstract}

Kata Kunci : Faktor-faktor pengaruh perubahan kondisi fisik lahan, prareklamasi, pascareklamasi

\begin{abstract}
The reclamation of Serangan Island in 1995-1998, resulted the physical change of the land that is to change the area of Serangan Island from 111 hectares to 481 hectares or to fourfold from the previous area, and to unite the area of the Serangan Island which on prereclamation in the form of island clusters. The first reclamation in Bali is of course due to a reasons, including the incompatibility of the initial planning objectives and the reality of postreclamation, where most of the land becomes empty land, whereas the original idea was to build megawisata facilities such as golf, resorts, lagoon, yatch club, beach club house, superlot development in the form of villas, other tourism support facilities, and marina / ferry. The reclamation has resulted in changes in the physical condition of the land on a macro (global) and micro (detailed) basis. Based on this phenomenon, will be sought to know the things behind the changing physical condition of land pascareklamasi. The research method used is qualitative descriptive with observation technique, survey and document. Sampling is done by purposive sampling. The results of this study are the factors behind the physical change of land post-reclamation such as : physical conditon of land factors, economic, institutional and other factors such as social factors, culture, and belief or faith.
\end{abstract}

Keywords: Influencing factors in physical changes of land, pre-reclamation, postreclamation. 


\section{Pendahuluan}

Fenomena reklamasi pada suatu kawasan menjadi isu sentral tak terkecuali reklamasi di Pulau Serangan yang dilaksanakan tahun 1995 dan terhenti tahun 1998. Awalnya reklamasi Pulau Serangan dilakukan oleh PT. Bali Turtle Island Development (PT. BTID) dengan tujuan membangun fasilitas megawisata seperti lapangan golf, resort, lagoon untuk sarana rekreasi air, yachtclub, beach club house, pembangunan superlot yang berupa villa, fasilitas penunjang pariwisata lainnya, serta marina/ferry. Namun proyek tersebut akhirnya terhenti tahun 1998 karena faktor krisis moneter,politik, sosial, budaya, dan faktor-faktor lainnya. (Woinarski. L., 2002 : 9)

Reklamasi yang dilakukan PT. BTID ini telah mengubah kondisi fisik lahan Pulau Serangan pra dan pascareklamasi secara makro/global dan mikro/perubahan guna lahan secara terperinci. Perubahan tersebut terbagi menjadi tiga jenis yaitu perubahan luasan dan ukuran, perubahan letak lahan dan juga perubahan pemanfaatan lahan. Secara makro/global, perubahan kondisi fisik lahan melalui reklamasi yang mengubah luas Pulau Serangan dari 111 hektar menjadi 481 hektar pasca reklamasi dan membagi zona kepemilikan lahan menjadi dua, yaitu wilayah Permukiman Penduduk dan wilayah PT. BTID yang mana dipisahkan oleh kanal wisata selebar 10 meter. Pascareklamasi, wilayah Permukiman Penduduk menyempit menjadi sekitar 46,5 hektar sedangkan wilayah yang dikuasai oleh PT. BTID sekitar 435 hektar, padahal wilayah Permukiman Penduduk prareklamasi seluas 111 hektar (seluruh daratan prareklamasi).

Sedangkan secara mikro/terperinci, beberapa kasus perubahan kondisi fisik lahan yang terjadi diantaranya : perubahan laut menjadi Taman Kota, LPD, KUD, Pasar Desa, Balai Konservasi Penyu dan fasilitas Watersport. Lahan tersebut direklamasi PT. BTID dan pascareklamasi sudah diserahkan ke Desa Pakraman Serangan sesuai kesepatan bersama. Selain itu terdapat pula perluasan Pura-Pura baik yang diemong oleh Puri Kesiman seperti Pura Dalem Sakenan dan Pesamuan Agung maupun yang diemong oleh Desa Pakraman Serangan seperti : Pura Puseh/Dalem Cemara, Pura Segara, Pura Dalem Khayangan, Pura Tanjung Sari, Pura Puncaking Tingkih, Pura Taman Sari dan Pura Tirta Arum. Pura-Pura di wilayah PT. BTID yang baru didirikan pascareklamasi diatas lahan bekas tegalan dan laut seperti misalnya: Pura Beji Dalem Sakenan, Pura Batu Api, dan Pura Batu Kerep.

Berdasarkan fakta perubahan kondisi fisik diatas, menarik untuk ditelusuri faktor-faktor yang melatarbelakangi perubahan kondisi fisik lahan tersebut. Terlebih lagi, reklamasi di Bali khususnya sangat sedikit kasus yang terjadi di Bali yaitu di Pulau Serangan dan yang sedang hangat-hangatnya dibahas adalah reklamasi Teluk Benoa. Berdasarkan rekomendasi penelitian ini, akan dapat dijadikan acuan dalam perencanaan suatu kawasan melalui reklamasi wilayah laut menjadi daratan.

\section{Metode Penelitian}

Penelitian ini menggunakan metode kualitatif deskriptif karena lokasi dan kasus penelitian yang memiliki nilai lokalitas tinggi karena kasus terhentinya reklamasi yang merubah kondisi fisik lahan dan kehidupan masyarakat hanya bisa dijumpai di Pulau Serangan saja. Pada pendekatan kualitatif ini, sampel penelitian diambil dengan teknik non random sampling dengan cara purposive sampling yaitu pengambilan sample dengan pertimbangan tertentu yang dianggap relevan atau dapat mewakili obyek yang diteliti serta 
dianggap memiliki informasi yang paling besar/berguna bagi peneliti. Misalnya mengambil sampel Bendesa Adat sebagai perwakilan dari Desa Pakraman Serangan, Kelihan Banjar merupakan pemimpin dari masing-masing Banjar di Desa Pakraman Serangan, pemilik usaha yang mewakili pelaku pemanfaatan lahan, serta tokoh masyarakat yang dianggap mengetahui permasalahan di lapangan terkait penelitian. Teknik pengumpulan dan analisis data menggunakan teknik observasi, survey, dan dokumen.

\section{Analisis Dan Pembahasan}

Perubahan kondisi fisik lahan pascareklamasi yang terjadi di Pulau Serangan disebabkan oleh faktor-faktor yang mempengaruhi perubahan tersebut. Menurut Gandasasmita, 2001, terdapat tiga faktor utama dalam menentukan perubahan pemanfaatan lahan yaitu faktor fisik lahan, faktor ekonomi, dan faktor kelembagaan. Disamping itu terkadang terdapat faktor sosial dan budaya serta faktor-faktor lainnya yang ikut pula mempengaruhi perubahan pemanfaatan lahan.

\subsection{Faktor Fisik Lahan}

Perubahan kondisi fisik lahan di Pulau Serangan sangat besar dipengaruhi oleh faktor adanya reklamasi oleh PT. BTID dari tahun 1995 hingga tahun 1998. Secara makro, reklamasi ini mengubah luas Pulau Serangan yang awalnya 111 hektar, menjadi 481 hektar (empat kali lipat dari luas aslinya) dan membuat wilayahnya menjadi satu (tidak terpecah-pecah oleh laut/gugusan pulau).

PRA REKLAMASI (SEBELUM 1995)
PROSES REKLAMASI (TAHUN 1995-1998)

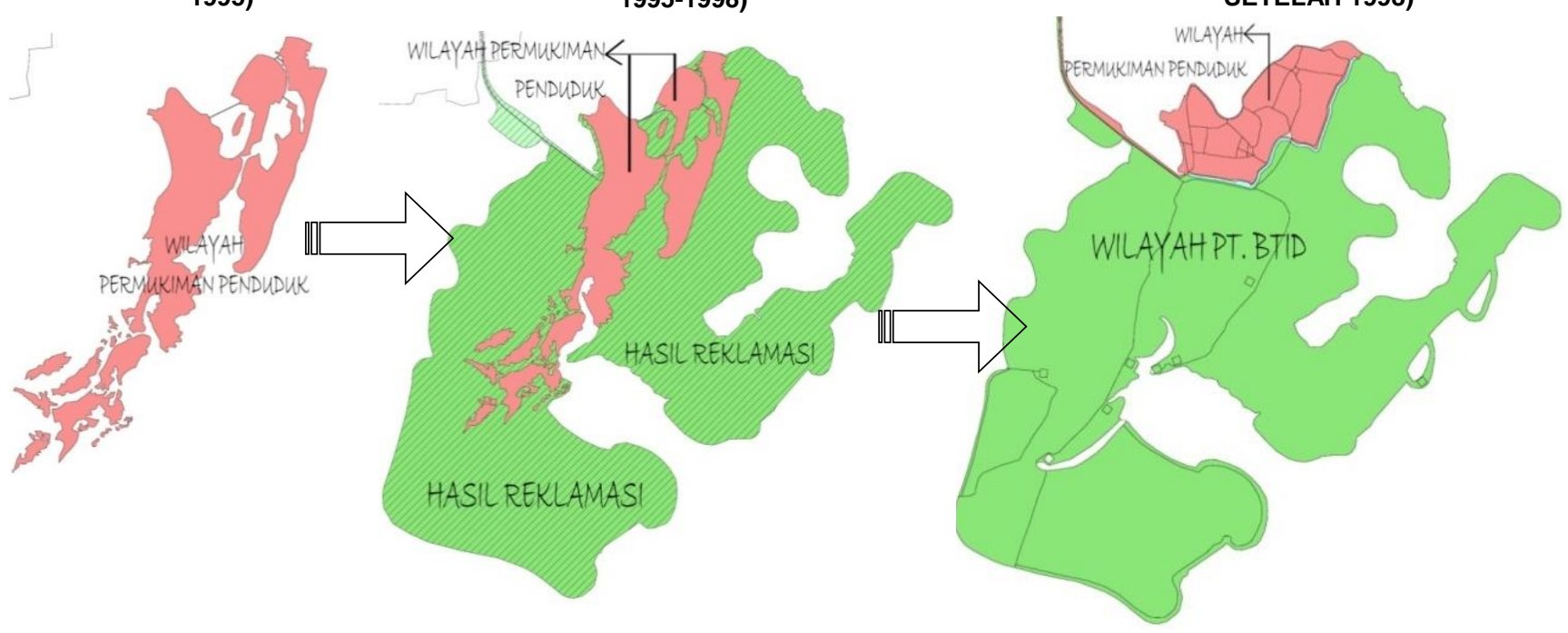

Gambar 1. Perubahan fisik melalui reklamasi menjadi faktor utama perubahan lahan (Sumber: Dokumentasi Pribadi, 2017)

Faktor fisik lahan yaitu masalah pengikisan air laut juga menjadi masalah utama yang terjadi sebelum adanya reklamasi. Dari data analisa peta dengan metode tumpang tindih (super impose) memperlihatkan adanya perbedaan morfologi pulau antara tahun 1948 dan tahun 1990. Dari analisa tersebut, diperoleh data terbenamnya daratan pulau sekitar 50\% dalam kurun waktu 42 tahun. Dan diperkirakan bahwa pengikisan air laut ini akan 
mengalami percepatan dengan semakin besarnya arus air laut di sisi barat pulau akibat semakin meningkatnya volume lalu lintas laut di Pelabuhan Benoa. Oleh karena itu, perlu segera diadakan suatu usaha penyelamatan secara menyeluruh, dalam arti pemecahan ini bukan hanya bersifat internal di pulau itu sendiri, tetapi juga pemecahan eksternal keadaan lingkungan sekitar pulau yang turut mempengaruhi (Kodam IX Udayana, 1995 : 10).

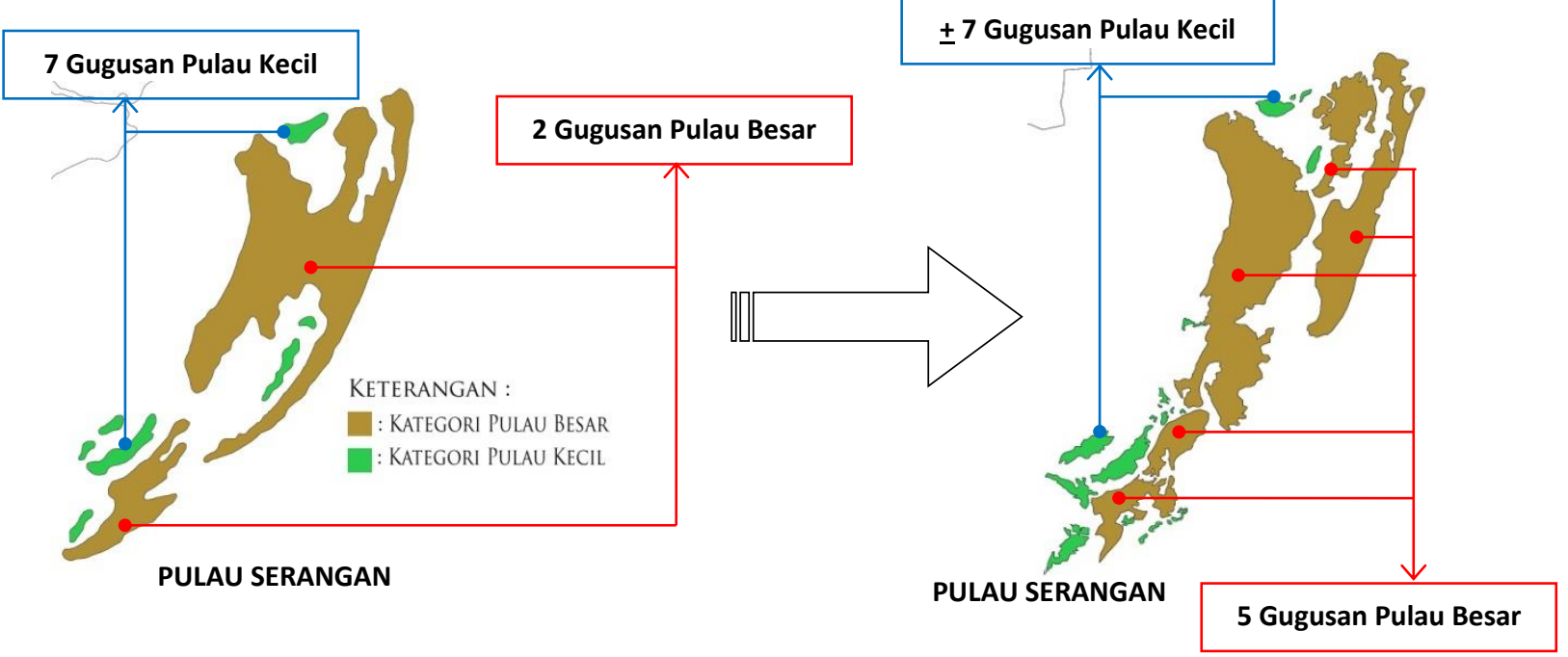

Gambar 2. Tingkat Abrasi Pulau Serangan yang Cukup Besar dari Tahun Ketahun

(Sumber: PT. BTID, 2017)

Tingkat abrasi ini terjadi di beberapa titik yaitu pada daratan tempat melasti yang lama kelamaan tenggelam menjadi laut dan direklamasi menjadi Tempat Melasti, Balai Konservasi Penyu, Bumi Perkemahan, dan Fasilitas Watersport. Pada pra reklamasi, tinggat perburuan penyu-penyu di Pulau Serangan sangat tinggi yang mendorong terwujudnya Balai Konservasi Penyu yang didirikan pascareklamasi. Selain itu pada kasus Banjar Kubu yang tukar guling dengan PT. BTID juga mengalamihal serupa. Secara fisik, letak lahan Banjar Kubu berada paling Selatan dan paling jauh dibandingkan BanjarBanjar lain yang letaknya mengelompok di bagian Utara Pulau Serangan. Jumlah warga Banjar Kubu yang hanya $23 \mathrm{KK}$ dengan jumlah rumah warga yang sedikit dan letaknya berjauhan juga menyebabkan kesan Banjar Kubu yang terisolir dan berbeda halnya dengan Banjar-Banjar lainnya yang berada pada kompleks permukiman yang padat sehingga susah terusik dengan keberadaan lahannya. Dengan titik permukiman yang sedikit di Banjar Kubu, menyebabkan lahan Banjar juga sepi dan rentan terjadinya perubahan pemanfaatan lahan. Lahan Banjar Kubu terletak di wilayah mayoritas tegalan dengan tingkat abrasi air laut yang tinggi. 

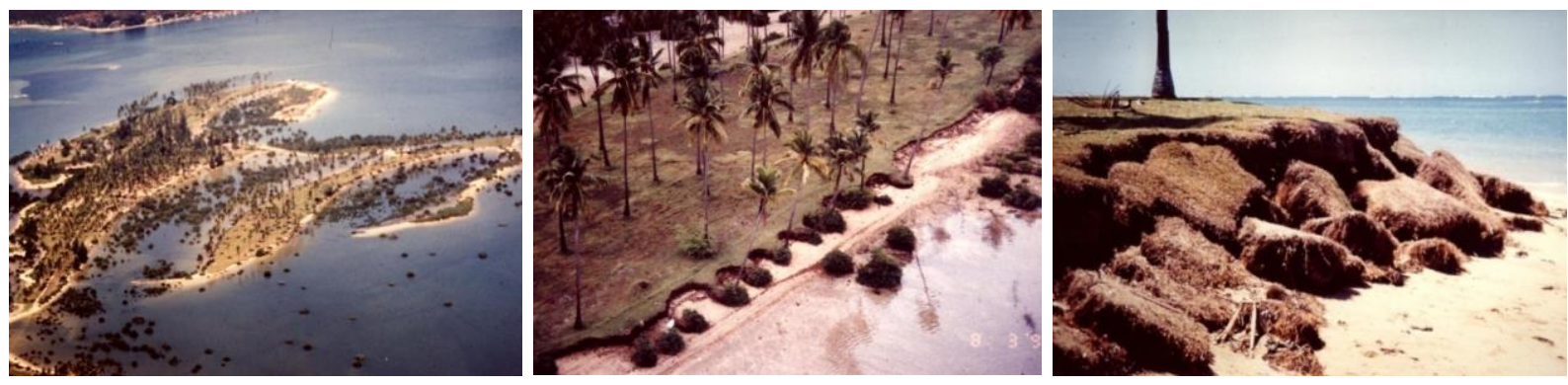

Gambar 3. Kondisi Abrasi di Pulau Serangan Prareklamasi

(Sumber: PT. BTID, 2017)

\subsection{Faktor Ekonomi}

Selain faktor fisik lahan, faktor ekonomi juga merupakan faktor utama yang mempengaruhi perubahan kondisi fisik lahan di Pulau Serangan. Faktor ekonomi yang dimaksudkan adalah ekonomi sub sistem yang diibaratkan seperti lingkaran-lingkaran kecil yang saling berhubungan, berinteraksi dan akhirnya membentuk suatu kesatuan sistem dalam lingkaran besar yang bergerak sesuai aturan yang ada (Astuti. M, 2009: 56).

Fakor ekonomi yang mempengaruhi adanya perubahan lahan melalui reklamasi adalah kedatangan investor PT. BTID yang melakukan pengembangan wisata di Pulau Serangan dengan cara reklamasi pulau berdasarkan permasalahan ekonomi yang terjadi di Pulau Serangan diantaranya (Kodam IX Udayana, 1995: 10):

\section{Masalah Income Penduduk}

Mata pencaharian penduduk Pulau Serangan pada umumnya adalah nelayan. Dengan mata pencaharian ini diperkirakan bahwa penduduk Pulau Serangan rata-rata berpenghasilan rendah. Maka, di dalam usaha pengembangan Pulau Serangan sebagai daerah rekreasi hendaknya mengikut sertakan penduduk mulai dari tahapan, perencanaan, pelaksanaan, dan operasionalnya. Dengan keikutsertaan penduduk dalam proses ini, selain menumbuhkan sense of belonging juga diharapkan dapat meningkatkan taraf hidup ke arah yang lebih baik.

\section{Masalah Pelestarian Penyu}

Penyu sebagai trade mark Pulau Serangan, belum dikelola secara profesional baik untuk kepentingan atraksi wisata, maupun untuk pelestarian dan kebutuhan konsumsi. Sehingga penduduk yang mengelolanya belum mendapatkan nilai tambah yang berarti dengan ternak penyu ini. Selain itu kendala dari habitat alam lingkungan Pulau Serangan tidak mendukung dan semakin tercemarnya laut oleh minyak dan sampah dari Benoa dan Suwung.

\section{Masalah Kurangnya Sarana Prasarana di Pulau Serangan}

Dari tahun ke tahun, jumlah pengunjung yang melakukan persembahyangan di Pura Sakenan pada Hari Raya Kuningan semakin meningkat. Peningkatan jumlah penduduk ini tidak disertai dengan peningkatan sarana dan prasarana yang memadai, seperti: pelabuhan dan pemberangkatan. Ruang terbuka di sekitar pulau yang bercampur aduk dengan warung makan/minum, masalah kebersihan dan kurangnya fasilitas toilet, dan lain-lain. 
4. Masalah Kondisi Pura Sakenan yang perlu diperluas dan diperbaiki karena memiliki arti khusus bagi masyarakat Bali.

5. Permasalahan rendahnya kesejahteraan masyarakat Pulau Serangan dilakukan dengan peningkatan ekonomi masyarakat melalui lapangan pekerjaan baru. Misalnya: pengelolaan pasar ikan, home stay, art shop, transportasi eksternal/internal. Menjadikan proyek pengelolaan Pulau Serangan yang terencana yang mengikutsertakan masyarakat secara langsung dalam perencanaan, pembangunan, dan pengelolaan kawasan wisata.

Sedangkan apabila dilihat secara mikro (secara terperinci), perubahan lahan laut menjadi Taman Kota Pulau Serangan juga pada dasarnya dipengaruhi oleh faktor ekonomi. Awalnya reklamasi ini dipergunakan untuk mempersatukan pulau yang dihuni warga Banjar Dukuh dengan pulau yang dihuni warga Banjar Kawan, Kaje, Tengah, dan Banjar Peken. Lahan baru hasil reklamasi kepemilikan PT. BTID ini rencananya dipergunakan untuk perluasan wilayah permukiman penduduk. Namun permintaan dari pemerintah dalam hal ini Desa Dinas untuk menjadikan lahan tersebut Taman Kota Pulau Serangan, menjadikan perubahan "skenario" pemanfaatan lahan. Selain itu, pembangunan dan pengelolaan Taman Kota Pulau Serangan sepenuhnya dikelola oleh Desa Dinas. Taman Kota selain difungsikan sebagai ruang terbuka, juga dipergunakan untuk arena jogging track, sepak bola, maupun parkir pemedek Pura Dalem Sakenan dan Pura Susunan Wadon. Saat piodalan inilah menjadi kesempatan bagi Desa Dinas untuk mendapatkan income dari hasil parkir kendaraan di Taman Kota Pulau Serangan.

Faktor ekonomi juga menjadi pengaruh perpindahan lahan yang dengan fungsi Pasar Desa, LPD dan KUD. Hal ini dikarenakan, Pasar Desa, LPD, dan KUD yang menjadi penggerak sektor perekonomian tradisional di Pulau Serangan kurang bisa berkembang dengan kondisi lahan dan fasilitas lahan yang minim dan terbatas. Pada prareklamasi, jantung perekonomian Masyarakat Pulau Serangan berada di depan Pura Desa yang mana terdapat lahan Pelaba Pura yang dimanfaatkan sebagai Pasar Desa, LPD, dan KUD. Sektor perekonomian ini kurang berkembang pada prareklamasi karena luas lahan yang ada relatif sempit yaitu sekitar 1,9 are serta akses jalan yang sempit yaitu 2 meter. Ditambah lagi tidak adanya bangunan-bangunan permanen tempat pedagang berjualan di Pasar Desa karena hanya mendirikan lapak-lapak kecil. Hal ini dikarenakan lahan ini difungsikan pula sebagai parkir pemedek Pura Desa sehingga tidak memungkinkan membangun tenda/bangunan permanen di atas lahan sempit dengan multi fungsi ini.

Adanya investor PT. BTID yang hendak melakukan reklamasi ini dimanfaatkan oleh masyarakat lokal Pulau Serangan untuk memindahkan Pasar Desa, LPD dan KUD di tempat yang lebih layak sehingga sektor perekonomian ini dapat berkembang dengan adanya lahan yang strategis dengan fasilitas berdagang yang layak karena dibuat dengan struktur bangunan permanen. Secara ekonomi, keberadaan Pasar Desa, LPD dan KUD baru yang berada di jantung wilayah permukiman Pulau Serangan memberikan keuntungan karena lahan bekas laut yang direklamasi oleh PT. BTID ini diberikan secara cuma-cuma oleh PT. BTID kepada Desa Pakraman Serangan, dengan kompensasi masyarakat Pulau Serangan berkewajiban mendukung kelancaran proyek reklamasi yang dilakukan oleh PT. BTID.

Faktor ekonomi juga mempengaruhi perluasan lahan areal melasti prareklamasi menjadi Balai Konservasi Penyu, Bumi Perkemahan, dan Fasilitas Watersport pascareklamasi. PT. BTID mereklamasi laut di pantai Timur Laut untuk memperluas areal melasti yang 
sebelumnya seluas 66 are menjadi seluas 3,15 hektar pada pascareklamasi. Pada perkembangannya, karena letak lahan yang sangat strategis di pantai Timur Laut Pulau Serangan serta memiliki nilai ekonomi yang tinggi dan luasnya lahan yang diberikan PT. BTID, maka lahan ini disewakan kepada pemilik modal untuk mendirikan fasilitas wisata watersport seperti Villa, Tempat Penyewaan Yatch, Balai Penelitian Terumbu Karang dan Rumput Laut, Restaurant, Marine Service, dan lain-lain yang mendatangkan pendapatan bagi Desa Pakraman Serangan. Selain itu, keberadaan Balai Konservasi Penyu sebagai tempat wisata pertama di Pulau Serangan juga menjadi pertimbangan disewakannya lahan sebagai areal melasti ini untuk fasilitas Watersport, sehingga zona obyek wisata di Pulau Serangan pascareklamasi dipusatkan di Pantai Timur Laut Pulau Serangan. Potensi banyaknya wisatawan lokal dan mancanegara yang datang pada masa pra dan pascareklamasi menjadi faktor ekonomi yang mendatangkan income bagi Desa Pakraman setempat dengan munculnya obyek wisata baru di Pulau Serangan pada pascareklamasi.

\subsection{Faktor Kelembagaan}

Perubahan kondisi fisik lahan yang terjadi di Pulau Serangan pascareklamasi juga dipengaruhi oleh faktor kelembagaan. Terjadinya reklamasi di Pulau Serangan menjadi pertanda perubahan fisik lahan dan perubahan non fisik kemasyarakatan. Perubahan fisik lahan secara makro yang ditandai dengan reklamasi laut menjadi daratan sehingga bentuk Pulau Serangan yang terdiri dari gugusan pulau berubah menjadi satu pulau melalui adanya reklamasi. Faktor kelembagaan yang mempengaruhi adanya reklamasi inilah yang juga mempengaruhi perubahan pemanfaatan lahan di Pulau Serangan. Di bawah ini akan disajikan mekanisme kelembagaan yang mempengaruhi perubahan kondisi fisik lahan secara makro di Pulau Serangan. 
INVESTOR

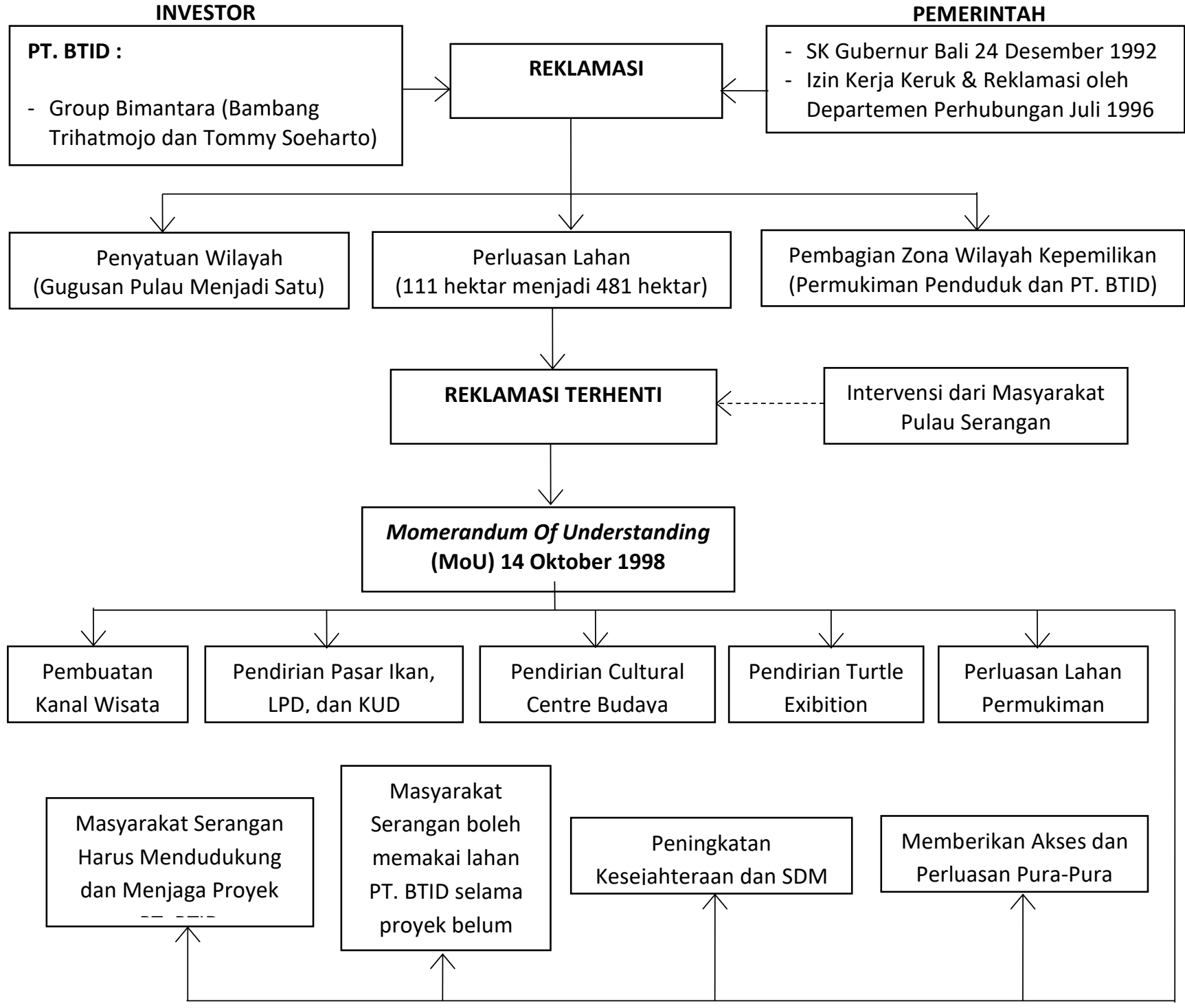

Diagram 1. Mekanisme Kelembagaan Perubahan Lahan Secara Makro di Pulau Serangan (Sumber: Rangkuman Wawancara Tokoh Masyarakat dan PT. BTID, 2017)

Berdasarkan diagram diatas, diketahui mekanisme secara kelembagaan yang mempengaruhi perubahan kondisi fisik lahan secara makro di Pulau Serangan adalah kedatangan Investor PT. BTID ke Pulau Serangan yang melakukan reklamasi dengan izin dari Gubernur dan Departemen Perhubungan. Reklamasi ini dilakukan denga tujuan "menyelamatkan kondisi fisik Pulau Serangan dari kerusakan yang lebih parah, peningkatan sosial ekonomi penduduk, pelestarian peninggalan budaya, dan peningkatan apresiasi budaya. Reklamasi inilah yang mengakibatkan perubahan fisik lahan di Pulau Serangan diantaranya penyatuan gugusan pulau, perluasan lahan menjadi empat kali lipat dari luas asli Pulau Serangan, dan pembagian zona wilayah kepemilikan. Reklamasi terhenti tahun 1998 sedangkan proyek pembangunan belum dilakukan memberikan efek intervensi dari masyarakat lokal Pulau Serangan akibat kerusakan tatanan sosial, budaya, ekonomi, serta kerusakan lingkungan. Akhirnya, tanggal 14 Oktober 1998 terjadi kesepakatan antara pihak PT. BTID dengan masyarakat lokal Pulau Serangan yang 
tertuang dalam Momerandum of Understanding (MoU). Dalam MoU tersebut terdiri dari 9 pasal, yaitu:

1. Memberikan lahan hasil reklamasi dan membantu pendirian Pasar Ikan, LPD, dan KUD sebagai sektor penggerak perekonomian tradisional di Pulau Serangan.

2. Mendirikan Cultural Centre Budaya untuk mendukung keberadaan Pura Sakenan.

3. Memberikan lahan hasil reklamasi dan mendirikan Turtle Conservation dan Edukation Center (TCEC) sebagai tempat konservasi dan edukasi tentang penyu.

4. Memberikan sejumlah lahan hasil reklamasi kepada masyarakat Pulau untuk perluasan lahan permukiman.

5. Mendirikan kanal wisata sebagai pemisah wilayah Permukiman Penduduk dengan wilayah PT. BTID. Kanal wisata dipergunakan untuk aktivitas wisata seperti lomba jukung, memancing, dan lain-lain.

6. Memberikan keleluasaan mendirikan bangunan komersial yang sifatnya semi permanen di wilayah kepemilikan PT. BTID dengan syarat apabila proyek pembangunan oleh PT. BTID dilangsungkan, bangunan-bangunan semi permanen yang didirikan oleh masyarakat lokal tersebut bisa dihancurkan oleh pihak PT. BTID.

7. Memberikan akses dan perluasan Pura-Pura baik yang berada di wilayah Permukiman Penduduk maupun di wilayah PT. BTID selama merupakan lahan hasil reklamasi.

8. Peningkatan sumber daya manusia seperti memberikan kesempatan utama bagi masyarakat Pulau Serangan untuk memperoleh lapangan pekerjaan di proyek PT. BTID maupun saat fasilitas megawisata selesai didirikan.

9. Masyarakat Pulau Serangan harus mendukung kelancaran proyek PT. BTID, dan juga menjaga dan mengamankan proyek.

Secara mikro, perubahan pemanfaatan lahan yang terdapat di wilayah Permukiman Penduduk merupakan penjabaran dari kesepakatan yang tertuang dalam MoU diantaranya perubahan laut menjadi fasilitas Pasar, LPD, KUD, perluasan Pura Sakenan, Pura Puseh/Dalem Cemara, Pura Segara, dan Pura Dalem Khayangan, serta Kuburan. Sedikit berbeda dengan hal diatas, pada kasus perubahan laut menjadi Taman Kota Pulau Serangan dan Fasilitas Watersport, pada dasarnya awalnya reklamasi laut oleh PT. BTID dipergunakan untuk perluasan wilayah permukiman dan perluasan areal melasti. Namun kenyataannya dipergunakan sebagai Taman Kota karena merupakan permintaan dari Pemerintah melalui Desa Dinas untuk memanfaatkan lahan bekas laut tersebut sebagai Taman Kota Pulau Serangan. Disamping itu lahan di bagian Timur Laut yang direklamasi PT. BTID untuk perluasan areal melasti, pada kenyataannya selain dipergunakan sebagai perluasan areal melasti, sebagian besar dipergunakan untuk Fasilitas Watersport yang memberikan keuntungan ekonomi bagi masyarakat lokal dan Desa Pakraman Serangan.

Sedangkan, pada wilayah kepemilikan PT. BTID, perubahan lahan Banjar Kubu dan permukiman warga Banjar Kubu menjadi lahan kepemilikan PT. BTID dilakukan atas dasar kesepakatan masyarakat dengan PT. BTID. Pada saat akan dilakukannya reklamasi, lahan Banjar Kubu dan warganya masuk dalam perencanaan fasilitas pariwisata PT. BTID. Oleh karena itu, PT. BTID berniat membeli lahan Banjar Kubu dan lahan permukiman warga. Akhirnya pada akhir tahun 1995 terjadi kesepakatan melalui perjanjian antara warga Banjar Kubu yang diwakili oleh Kelihan Banjar Kubu dengan PT. BTID mengenai tukar guling lahan Banjar Kubu dan permukiman warga Banjar Kubu serta perjanjian antara Kelihan Banjar Dukuh dengan PT. BTID mengenai perluasan lahan Banjar Dukuh yang semula seluas 2,5 are menjadi seluas 3,5 are. Terdapatnya Pura-Pura 
baru pascareklamasi seperti Pura Batu Api dan Pura Batu Kerep serta perluasan PuraPura seperti Pura Tanjung Sari, Pura Puncaking Tingkih, Pura Taman Sari dan Pura Tirta Arum juga didasarkan kesepakatan yang tertuang dalam MoU yang menyebutkan memberikan akses dan perluasan Pura-Pura baik di wilayah Permukiman Penduduk maupun di wilayah PT. BTID.

\subsection{Faktor-Faktor Lainnya}

Faktor-faktor lain seperti faktor sosial, budaya, kebiasaan, dan kepercayaan, juga turut mempengaruhi perubahan kondifi fisik lahan pascareklamasi di Pulau Serangan. Pascareklamasi, timbul budaya/kebiasaan masyarakat untuk menimbun/mereklamasi lahan pesisir mereka dengan cara konvensional untuk meminimalisir tingkat abrasi air laut yang cukup tinggi. Masyarakat setempat mengambil pasir di bagian lahan yang memiliki topografi yang tinggi dan menimbun sedikit demi sedikit lahan permukiman mereka yang berbatasan langsung dengan laut. Dengan kedatangan investor PT. BTID yang berencana mereklamasi besar-besaran inilah yang mempengaruhi masyarakat setempat untuk menyetujui perencanaan investor tersebut karena mereka tidak perlu bersusah payah lagi menimbun wilayah mereka dengan cara konvensional yang membutuhkan tenaga ekstra namun menghasilkan kuantitas yang sedikit. Budaya atau kebiasaan masyarakat setempat yang melakukan penimbunan/reklamasi pun hilang digantikan dengan reklamasi PT. BTID menggunakan alat-alat berat yang jauh lebih efektif dalam menghasilkan kuantitas reklamasi di Pulau Serangan.
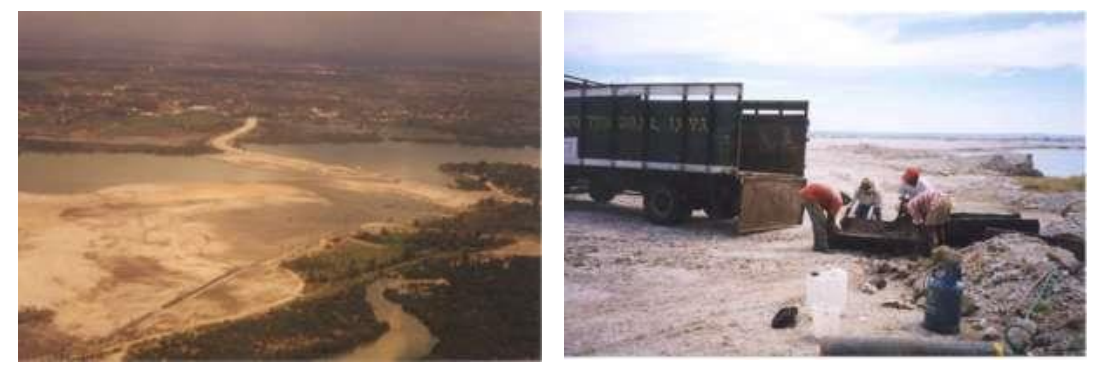

Gambar 4. Proses Reklamasi Pulau Serangan Tahun 1995-1998 (Sumber: PT. BTID, 2017)

Secara lebih spesifik, perubahan lahan Banjar Kubu dan permukiman warga menjadi lahan milik PT. BTID juga disebabkan faktor kedekatan secara sosial yaitu masyarakat Banjar Kubu ingin hidup berkelompok dengan warga Banjar lainnya di permukiman padat penduduk di bagian Utara Pulau Serangan. Pada prareklamasi, warga Banjar Kubu berada jauh dengan wilayah padat penduduk sehingga kurang memiliki kedekatan secara sosial. Dengan bergabungnya warga Banjar Kubu dengan warga Banjar dukuh, secara psikis, warga Banjar Kubu merasa aman dan tidak was-was lagi karena sudah berada di wilayah permukiman padat penduduk yang secara hierarki memiliki kedekatan dalam interaksi antar penduduk di dalam wilayah permukiman, disamping memang tidak terdapat pihan/opsi lain bagi warga Banjar Kubu untuk tetap bertahan di lahan eksisting mereka dengan kedatangan investor PT. BTID dan absolutnya/tidak terbatasnya tingkat kekuasaan pemerintah pada masa itu yang tidak segan-segan memberikan kekerasan fisik kepada masyarakat yang berani melawan kebijakan pemerintah.

Perluasan lahan Kuburan juga dipengaruhi oleh faktor sosial budaya masyarakat yang sebagian besar menginginkan wilayah permukiman dengan Kuburan dijadikan satu. 
Seperti telah diketahui, masyarakat Pulau Serangan prareklamasi sudah membudaya membawa mayat ke kuburan dengan menyeberangi lautan dangkal yang terkadang mencapai ketinggian orang dewasa saat air laut pasang. Kondisi ini mengakibatnya masyarakat enggan dan malas ikut menyeberangi laut sehingga hanya sedikit orang yang ikut menyeberang laut untuk membawa mayat. Kesepakatan antara pihak Desa Pakraman Serangan dengan PT. BTID ini untuk memperluas lahan Kuburan termasuk menyatukan wilayah daratan di depan Kuburan untuk menyikapi fenomena tersebut. Akibatnya pasca reklamasi, setiap ada ritual kematian, hampir seluruh kepala keluarga yang ada di Pulau Serangan, ikut serta membawa dan mengiringi mayat ke Kuburan karena kemudahan akses daratan hasil reklamasi dengan kondisi jalan yang sangat memadai. Namun, tidak sedikit pula warga masyarakat yang merasa kehilangan dan merindukan tradisi mereka pada masa prareklamasi tersebut. Sebagian orang beranggapan kemungkinan tradisi membawa mayat ke Kuburan dengan menyeberangi laut ini hanya terdapat di Pulau Serangan saja akibat wilayah permukiman dan kuburan mereka berada di wilayah daratan yang berbeda karena dipisahkan oleh laut.

Selanjutnya, pada kasus perubahan laut menjadi Pasar Desa, LPD, dan KUD yang baru disebabkan secara sosial masyarakat Pulau Serangan prareklamasi merasa kurang nyaman dalam bertransaksi jual beli di lahan yang sempit ini, karena berjubelnya pedagang dan pembeli di atas lahan yang sempit dengan lebar jalan padat permukiman yang hanya selebar 2 meter. Hal ini menyebabkan kurang kondusifnya situasi di tempat ini dengan crowdednya pengguna jalan dengan pedagang dan pembeli yang melakukan transaksi di pasar pinggir jalan ini. Terlebih lagi saat piodalan Pura Desa, menjadikan tingkat kesemrawutan semakin tinggi karena benturan aktivitas pedagang dan pembeli di Pasar Desa dengan pemedek Pura Desa yang memarkirkan kendaraan untuk tangkil ke Pura Desa. Hal ini berlaku pula pada LPD dan KUD yang berada pada satu lahan di atas lahan sempit yang menyebabkan warga enggan/malas datang ke LPD dan KUD karena berjubel dan semrawutnya sirkulasi di areal ini.

Perubahan laut menjadi Balai Konservasi Penyu juga dikarenakan pada prareklamasi budaya masyarakat untuk berburu daging penyu yang parah sehingga mengancam kelestarian populasi penyu. Mereka yang berburu penyu tersebut mayoritas merupakan warga masyarakat Pulau Serangan. Ironis melihat kenyataan Pulau yang dikenal sebagai "Pulau surganya penyu" menjadi daerah tempat pembantaian penyu di Bali. Oleh karena itu, PT. BTID memberikan lahan hasil reklamasi laut untuk didirikan Balai Konservasi Penyu yang dinamakan Turtle Conservation dan Education Center (TCEC). Fungsi dari tempat ini sebagai tempat penangkaran penyu utamanya jenis penyu langka yang terancam punah sekaligus pula sebagai media pembelajaran untuk masyarakat dari berbagai kalangan usia akan pentingnya pelestarian penyu hingga masih bisa kita jumpai di masa yang akan datang. Fungsi lain dari pendirian TCEC ini adalah untuk merubah stigma di masyarakat luas tentang Pulau Serangan yang dipakai sebagai tempat pembantaian penyu, sebaliknya Pulau Serangan justru dipergunakan sebagai tempat pelestarian penyu dan obyek wisata penyu bagi masyarakat dan wisatawan.

Pada kasus perubahan laut menjadi Pura yang diemong Puri Kesiman yaitu Pura Beji Dalem Sakenan yang didirikan tahun 2008, dipengaruhi oleh faktor kepercayaan yaitu adanya pawisik untuk mendirikan tempat pemandian Ida Bhatara yang berstana di Pura Dalem Sakenan. Pawisik ini disampaikan langsung oleh Pemangku Pura Dalem Sakenan bernama I Gusti Ketut Lengur yang menceritakan mengenai mimpinya. Sedangkan 
perubahan laut menjadi Pura Batu Api yang diemong Desa Pakraman Serangan juga didasarkan atas pawisik/sunia dari Ida Bhatara melalui mimpi Bendesa Pakraman Serangan bernama Gede Mudana Wiguna untuk mendirikan Pura Batu Api. Sama halnya dengan Pura Batu Api, adanya Pura Batu Kerep yang ada pascareklamasi tepatnya tahun 2008 juga karena adanya pawisik dari Pemangku Pura Pat Payung bernama Ketut Sudiarsa yang bermimpi bahwa Ida Bhatara yang berstana di Pura Dalem Peed Nuda Dua menyuruh membuatkan pelinggih penyawangan di ujung Utara Pulau Serangan yang segaris lurus dengan Pura Pat Payung sebagai tempat melancaran beliau menuju Pura Dalem Peed di Nusa Dua ataupun sebaliknya. Pura ini dinamakan Pura Batu Kerep.

\section{Penutup}

Berdasarkan pembahasan serta analisis yang dipaparkan sebelumnya maka diperoleh kesimpulan bahwa faktor-faktor yang mempengaruhi perubahan kondisi fisik Pulau Serangan pascareklamasi terdiri dari 4 faktor yaitu:

1. Faktor fisik lahan yaitu pengikisan air laut serta tingkat abrasi yang tinggi di Pulau Serangan prareklamasi.

2. Faktor ekonomi yaitu masalah income penduduk yang rata-rata berpenghasilan rendah dan mayoritas sebagai nelayan, masalah pelestarian penyu dan tercemarnya laut oleh minyak dan sampah dari Benoa dan Suwung, masalah kurangnya sarana prasarana, kondisi Pulau Sakenan yang perlu diperluas dan diperbaiki, serta mengikutsertakan masyarakat dalam perencanaan, pelaksanaan dan pengelolaan kawasan wisata melalui reklamasi.

3. Faktor kelembagaan yaitu kedatangan Investor PT. BTID untuk melakukan reklamasi berdasarkan izin Gubernur dan Departemen Perhubungan yang tujuannya menyelamatkan kondisi fisik Pulau Serangan dari kerusakan yang lebih parah, peningkatan sosial ekonomi penduduk, pelestarian peninggalan budaya, dan peningkatan apresiasi budaya. Pascareklamasi terhenti tahun 1998, terdapat 9 butir MoU kesepakatan antara pihak PT. BTID dengan masyarakat setempat yang intinya agar masyarakat setempat tidak terlalu rugi dengan dihentikannya mega proyek ini.

4. Faktor-faktor lain seperti faktor sosial, budaya, kebiasaan dan kepercayaan seperti timbulnya budaya masyarakat prareklamasi yang menimbun/mereklamasi lahan pesisir dengan cara konvensional untuk meminimalisir tingkat abrasi laut yang tinggi, faktor kedekatan sosial warga Banjar Kubu yang ingin tinggal berdekatan dengan komplek Banjar-Banjar lainnya, keinginan untuk menghentikan kebiasaan berburu penyu yang nyaris punah, serta kepercayaan melalui mimpi dari beberapa tokoh masyarakat setempat untuk membangun Pura-Pura di wilayah reklamasi laut.

\section{Ucapan Terima Kasih}

Terima kasih diucapkan kepada Kementrian Riset, Teknologi, dan Pendidikan Tinggi Republik Indonesia (KEMENRISTEKDIKTI) karean telah mendanai penelitian ini secara penuh dalam rangka hibah penelitian dosen pemula tahun pelaksanaan 2017. Ucapan terima kasih juga diucapkan kepada lembaga penelitian Universitas Warmadewa yang telah menjembatani kerjasama antara tim peneliti dengan KEMENRISTEKDIKTI sehingga dapat berjalan dengan semestinya. 


\section{Daftar Pustaka}

Direktorat Jenderal Pemberdayaan Masyarakat dan Desa. 2007. Profil Desa dan Kelurahan Serangan. Departemen Dalam Negeri, Denpasar.

Kodam IX Udayana. 1987. Pelestarian dan Pengembangan Lingkungan Fisik dan Budaya Pulau Serangan. Denpasar: PT. Bina Cipta AdiBuana.

Muhadjir, Noeng. 1996. Metodologi Penelitian Kualitatif, Pendekatan Positivistik, Rasionalistik, Phenomenologik, dan Realisme Metaphisik. Yogyakarta: Rake Sarasin.

Wisnawa, I Made. 2002. Model Pemanfaatan Pulau Serangan di Kota Denpasar Pasca Reklamasi. Tesis. Semarang: Universitas Diponegoro. 